\title{
Rancang Bangun Pembangkit Listrik Portable Tenaga Surya dan Angin Dengan Sistem Hybrid Untuk Tempat Pengungsian Bencana Alam
}

\section{Dandi Widhi Ramadhan*, Yusuf Ismail Nakhoda, Ni Putu Agustini}

Teknik Elektro S1 Institut Teknologi Nasional Malang, Malang, Indonesia

*dandi_w33@gmail..com

Kata Kunci :

Portable

Renewable Energy

Disaster

\section{ABSTRAK}

Beberapa waktu lalu Kota Palu dan sekitarnya mendapat musibah bencana alam yaitu Tsunami. Disaat terjadi Tsunami semua jaringan listrik dan komunikasi rusak dan porakporanda, hasilnya semua listrik, penerangan, dan komunikasi lumpuh atau mati total. Disaat tim SAR (Search and Rescue) melakukan operasi pencarian korban yang terkena bencana sempat mengalami kendala, yaitu minimnya penerangan dan jaringan komunikasi. Sama halnya dengan masyarakat yang mengungsi di pengungsian mengeluhkan kurangnya penerangan, jaringan listrik, serta jaringan komunikasi. Terinspirasi dari hal tersebut penulis meiliki gagasan untuk memanfaatkan Photovoltaic (panel surya) atau yang dikenal dengan pembangkit listrik tenaga surya (PLTS) dan dapat dihybrid dengan pembangkit listrik tenaga bayu (PLTB) yang menjadi salah satu solusi disaat terjadi bencana alam dan seluruh pasokan bahan bakar minyak (BBM) ikut terhambat, hingga membutuhkan waktu lama untuk menuju ke lokasi bencana alam.Dengan model portable diharapkan dapat di bawa ke lokasi pengungsian bencana alam serta mudah dioperasikan oleh masyarakat umum sehingga tidak membutuhkan tenaga ahli untuk mengoperasikannya. Sehingga dengan adanya pembangkit listrik ramah lingkungan ini dapat membantu para pengungsi serta tim SAR yang melakukan operasi pencarian korban di tempat bencana.sia

Sometime ago in Palu City and its surroundings had a Tsunami, which is known as natural disaster. When it occurred, all the electricity and communication networks were damaged. As the result all of the electricity, lighting, and communication were paralyzed or totally collapse. When the SAR (Search and Rescue) team conducted a search operation for the victims, they were experiencing multiple problems, such as the lack of lighting and communication networks. Likewise, the people who were moved to the refugee camps also complained about those things as well. Inspired by this, the writer has the idea to utilize photovoltaic (solar panels) or known as solar power plants and can be hybridized with wind power plants which is one of the solutions when natural disasters occur and the entire fuel supply oil (BBM) is hampered, 
which takes a long time to get to the location of the natural disaster. Based on this portable model, the tool is expected to be brought to a natural disaster refuge site and it is easily operated by the community so that it doesn't need experts to operate it. By the existence of an environmentally friendly power plant can help the refugees as well as the SAR team conducting search operations at the disaster site.

\section{Pendahuluan}

Perkembangan teknologi pembangkitan energi listrik khususnya energi terbarukan saat ini sudah cukup maju seiring dengan meningkatnya perkembangan teknologi, industri, dan informasi. Namun pada kenyataannya kemajuan itu belum semua diterapkan dan dirasakan oleh masyarakat, sehingga penggunaan energi alternatif di Indonesia belum bisa merata. Pertumbuhan warga sangat pesat dan disertai dengan pertumbuhan perumahan, keduanya mengakibatkan penyediaan listrik harus meningkatkan kapasitas daya lebih dari apa yang tersedia sekarang.

Melalui pendekatan terhadap masyarakat seperti promosi, sosialisasi, dan edukasi, maka pembangkitan energi terbarukan lambat laun akan terwujud. Salah satunya sistem pembangkit paling murah dan mudah didapatkan yang mungkin bisa dimiliki oleh masyarakat umum, yaitu sumber daya energi terbarukan dengan memanfaatkan sumber energi dari alam seperti matahari, angin, dan air. Energi listrik yang dihasilkan selain bisa digunakan untuk masyarakat umum bisa juga digunakan untuk tempat pengungsi serta tim SAR (Search and Rescue) saat ada bencana alam.

28 September 2018 Kota Palu dan sekitarnya mendapat musibah bencana alam yaitu Tsunami. Disaat terjadi Tsunami semua jaringan listrik dan komunikasi rusak dan porakporanda, hasilnya semua listrik, penerangan, dan komunikasi lumpuh atau mati total. Disaat tim SAR (Search and Rescue) melakukan operasi pencarian korban yang terkena bencana sempat mengalami kendala, yaitu minimnya penerangan dan jaringan komunikasi. Sama halnya dengan masyarakat yang mengungsi di pengungsian mengeluhkan kurangnya penerangan, jaringan listrik, serta jaringan komunikasi.

Memanfaatkan Photovoltaic (panel surya) atau yang dikenal dengan pembangkit listrik tenaga surya (PLTS) dan dapat dihybrid dengan pembangkit listrik tenaga bayu (PLTB) adalah salah satu solusi yang baik. Dimana disaat terjadi bencana alam seluruh pasokan bahan bakar minyak (BBM) ikut terhambat dan membutuhkan waktu lama untuk menuju ke lokasi bencana alam. Dengan demikian maka sumber energi yang dapat dimanfaatkan adalah sumber energi baru terbarukan.

Terinspirasi dari hal tersebut, penulis memiliki suatu implementasi sistem pembangkit listrik energi baru terbarukan berupa pembangkit listrik tenaga surya (PLTS) dan pembangkit listrik tenaga bayu (PLTB) yang portable atau mudah di bawa kemana saja khususnya disaat terjadi bencana alam dan untuk pembangkit tersebut mudah dioperasikan oleh masyarakat umum sehingga tidak perlu membutuhkan tenaga ahli untuk mengoperasikannya. Sehingga dengan 
adanya pembangkit listrik ramah lingkungan ini dapat membantu para pengungsi serta tim SAR yang melakukan operasi pencarian korban di tempat bencana. Mungkin disuatu saat alat ini dapat memenuhi kebutuhan listrik untuk jaringan komunikasi.

\section{Landasan Teori}

\subsection{Sel Surya}

Sel surya atau solar cell merupakan elemen aktif struktur dioda yang terbuat dari semikonduktor atau polimer dan berfungsi untuk mengkonversi cahaya matahari menjadi energi listrik. Konversi energi ini dihasilkan dari irradiansi cahaya pada sel surya, dan hal ini diketahui sebagai efek Photovoltaic. Ketika cahaya mengenai sel surya, energi foton yang lebih besar dari energi band gap akan mengeksitasi elektron valensi, sehingga pasangan electronhole akan tergenerasi yang kemudian pasangan electron-hole ini akan menimbulkan medan listrik.

Pada umumnya sel surya terbuat dari bahan semikonduktor silikon, tetapi sekarang ini telah dikembangkan DSSC. DSSC merupakan sel surya fotoelektrokimia yang menggunakan elektrolit sebagai medium transport muatan, berbahan dasar polimer tumbuhan yaitu antosianim, klorofil, dan xantofi.

\section{Cara Kerja Sel Surya}

Struktur sel surya yaitu berupa dioda sambungan (junction) antara dua lapisan tipis yang terbuat dari bahan semikonduktor yang masing-masing diketahui sebagai semikonduktor jenis $p$ (positif) dan semikonduktor jenis $n$ (negatif). Semikonduktor jenis $n$ merupakan semikonduktor yang memiliki kelebihan elektron, sehingga kelebihan hole yang mengakibatkan kelebihan muatan positif.

Proses pengubahan atau konversi cahaya matahari menjadi listrik ini karena divais sel surya memiliki struktur dioda, yaitu tersusun atas dua jenis semikonduktor, yakni jenis $n$ dan jenis $p$. Caranya dengan manambahkan unsur lain ke dalam semikonduktor, maka kita dapat mengontrol jenis semikonduktor tersebut, seperti diilustrasikan pada gambar 2.1.

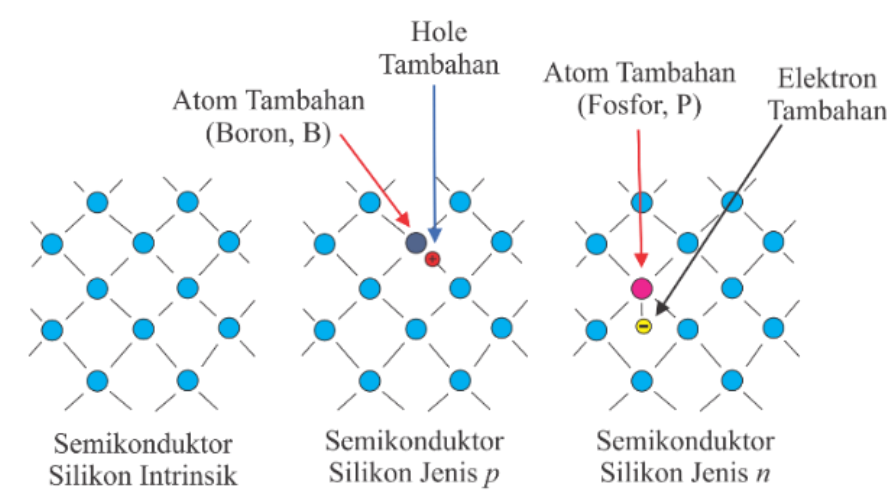

Gambar 1 Ilustrasi Pembuatan Silikon Jenis $p$ dan $n$.

Dua jenis semikonduktor $n$ dan $p$ ini jika disatukan akan membentuk sambungan $p n$ atau dioda $p$ - $n$ atau sambungan metalrugi/metallurgical junction yang dapat digambarkan sebagai berikut: 
1. Semikonduktor jenis $p$ dan $n$ sebelum disambung:

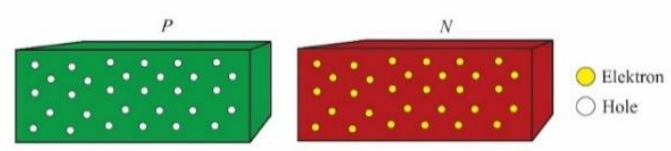

Gambar 2 Semikonduktor Jenis $N$ dan $P$ Sebelum Disambung.

2. Perpindahan elektron-elektron dari semikonduktor $n$ menuju semikonduktor $p$, dan perpindahan hole dari semikonduktor $p$ menuju semikonduktor $n$, proses ini disebut difusi.

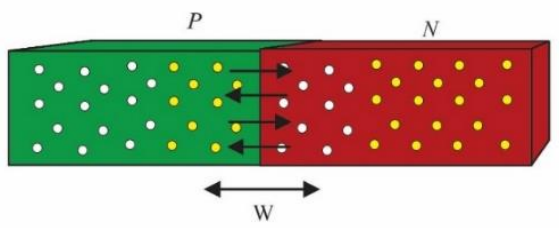

Gambar 3 Semikonduktor Jenis $N$ dan $P$ Sesudah Tersambung.

3. Elektron dari semikonduktor $n$ bersatu dengan hole pada semikonduktor $p$ yang mengakibatkan jumlah hole pada semikonduktor $p$ akan berkurang. Daerah ini akhirnya berubah menjadi lebih bermuatan negatif. Pada saat yang sama Hole dari semikonduktor $p$ bersatu dengan elektron yang ada pada semikonduktor $n$ mengakibatkan jumlah elektron di daerah ini berkurang. Daerah ini akhirnya lebih bermuatan positif.

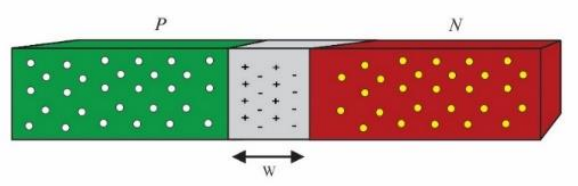

Gambar 4 Daerah Deplesi (Depletion Region) Pada Sambungan Semikonduktor.

4. Daerah negatif dan positif ini disebut dengan daerah deplesi (Depletion Region) dengan jarak huruf W.

5. Elektron yang difusi ke $p$ akan mengisi holes yang ada di daerah junction layer $p$ sehingga daerah tersebut menjadi intrinsik.

6. Dikarenakan adanya perbedaan muatan positif dan negatif di daerah deplesi, maka timbul dengan sendirinya medan listrik internal E dari sisi positif ke sisi negatif. Gambar 5 menunjukkan garis medan listrik (E) pada sambungan semikonduktor.

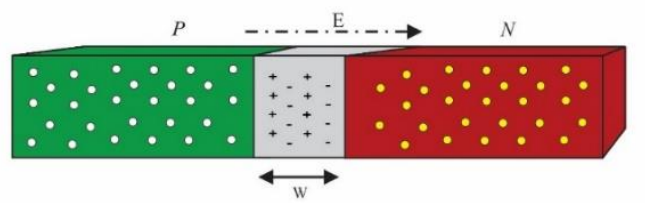

Gambar 5 Garis Medan Listrik E Pada Sambungan Semikonduktor. 
7. Adanya medan listrik mengakibatkan sambungan $p n$ berada pada titik setimbang, yakni saat dimana jumlah hole yang berpindah dari semikonduktor $p$ ke $n$ dikompensasi dengan jumlah hole yang tertarik kembali kearah semikonduktor $p$ akibat medan listrik E. Pada sambungan dioda $p n$ inilah proses konversi cahaya matahari menjadi listrik terjadi. Gambar 6 menunjukkan proses aliran arus listrik pada sambungan $p n$.

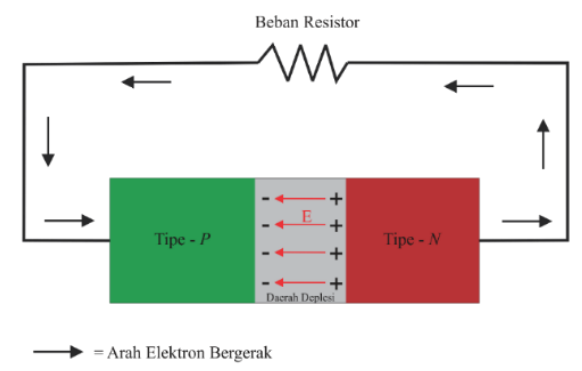

Gambar 6 Proses Aliran Arus Listrik Pada Sambungan pn.

Elektron ekstitasi yang dihasilkan oleh bagian $p$ akan tertarik menuju ke bagian $n$ karena medan listrik yang ada di depletion layer. Hal ini menyebabkan tegangan bagian $n$ menjadi lebih negatif dan bagian $p$ menjadi lebih positif. Perbedaan potensial antara $p$ dan $n$ ini dapat dimanfaatkan energinya dengan menyalurkan melalui beban resistor beban. Gambar 7 menunjukkan garis penyerapan cahaya matahari pada sel surya.

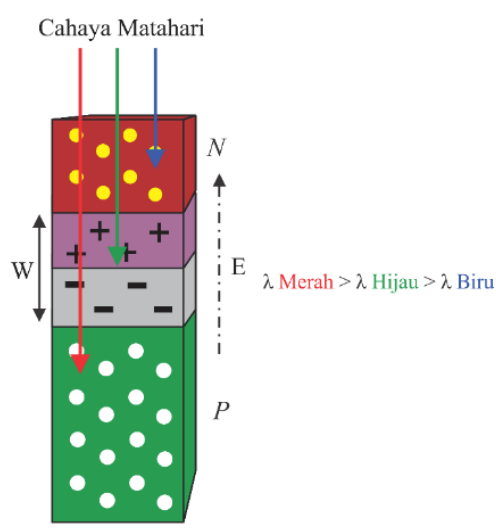

Gambar 7 Penyerapan Cahaya Matahari Pada Sel Surya.

Ketika sambungan semmikonduktor ini terkena cahaya matahari, maka elektron mendapat energi dari cahaya matahari untuk melepaskan dirinya dari semikonduktor $n$, daerah deplesi maupun semikonduktor. Terlepasnya elektron ini meninggalkan hole pada daerah yang ditinggalkan oleh elektron yang disebut dengan fotogenerasi elektron-hole (electron-hole photogeneration) yakni, terbentuknya pasangan elektron dan hole akibat cahaya matahari. Gambar 8 menunjukkan proses electron-hole photogeneration pada sambungan semikonduktor. 


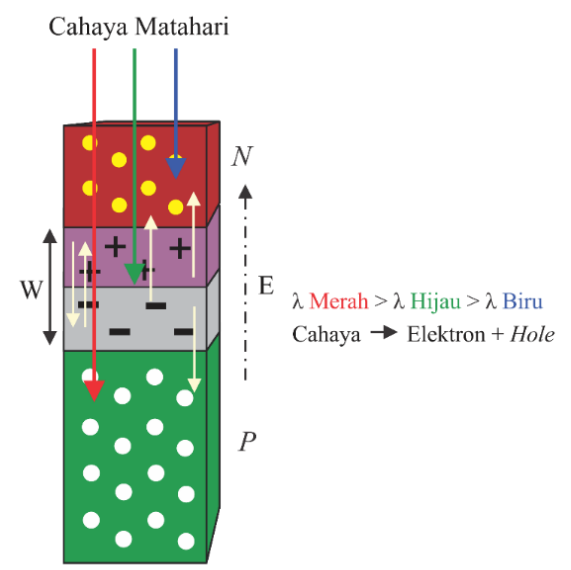

\section{Gambar 8 Electron-hole Photogeneration Pada Sambungan Semikonduktor.}

Cahaya mataharii dengan panjang gelombang (dilambangkan dengan simbol $\lambda$ (Lambda) yang berbeda, membuat fotogenerasi pada sambungan $p n$ berada pada bagian sambungan $p n$ yang berbeda pula. Spektrum meah dari cahaya matahari yang memiliki panjang gelombang lebih panjang, mampu menembus daerah deplesi hingga terserap di semikonduktor $p$ yang akhirnya menghasilkan proses fotogenerasi di sana.

\section{Kurva Karakteristik Sel Surya}

Kurva I-V merupakan kurva karakteristik arus tegangan yang menggambarkan unjuk kerja satu divais sel surya. Kurva I-V sel surya merupakan superposisi kurva I-V dioda dari sel surya pada keadaan gelap dengan arus yang dibangkitkan oleh cahaya (Light Generated Current). Cahaya memberikan efek pada pergeseran kurva I-V sel surya yang berarti sel surya telah menghasilkan daya ${ }^{[\text {S. Honsberg.2009] }}$ Dapat dilihat pada gambar 9 adalah rangkaian ekivalen sel surya.

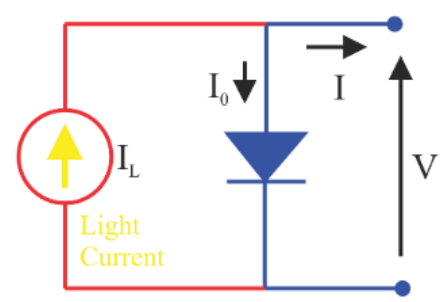

\section{Gambar 9 Rangkaian Ekivalen Sel Surya.}

Gambar 10 (a), (b), (c) merupakan gambar efek pergeseran kurva I-V pada sel surya akibat adanya iluminasi cahaya yang diterima sel surya:
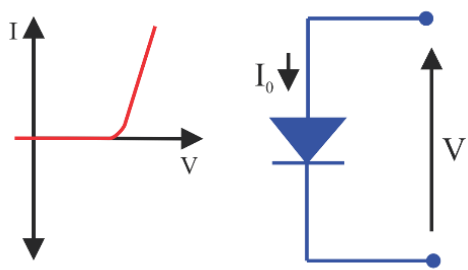

(a). Tanpa iluminasi cahaya, sel surya memiliki karakteristik kelistrikan yang sama dengan sebuah dioda. 


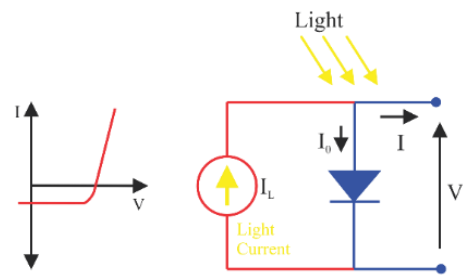

(b). Ketika cahaya mengenai sel surya, kurva I-V mengalami pergeseran, menunjukkan sel surya mulai menghasilkan daya (energi listrik).

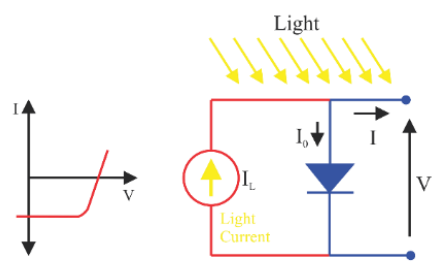

(c). Semakin besar iluminasi cahaya yang diterima, semakin besar pula pergeseran kurva I (arus).

Gambar 11 memperlihatkan rangkaian untuk memperoleh karakteristik kurva I-V sel surya.

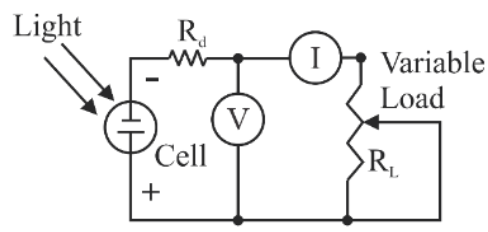

Gambar 11 Diagram Sirkuit Untuk Kurva I-V.

Dengan mengatur nilai hambatan dari nol sampai nilai semakin besar akan didapatkan kurva karakteristik arus dan tegangan sel surya. Bila nilai hambatan diatur sama dengan nol, maka didapat arus hubung singkat (Short Circui Current) atau Isc sebagai fungsi irradiance sel surya. Bila nilai hambatannya sangat besar, maka tidak ada arus yang melewatinya, kondisi ini sama dengan memutus penghubung pada ampere meter, dan hasil menunjukkan pada pengukur voltmeter merupakan tegangan tanpa beban (Open Circuit Voltage) atau Voc. Gambar 12 memperlihatkan kurva karakteristik sel surya pada saat penyinaran dan keadaan gelap.

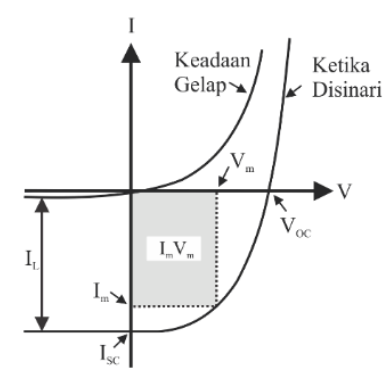

Gambar 12 Karaktersitik Sel Surya Pada Penyinaran dan Gelap.

Dari gambar 12 menunjukkan karakteristik sel surya yang disinari terdapat tiga titik, yaitu tegangan tanpa beban (Voc), arus hubung singkat (Isc) dan titik daya maksimum yang merupakan perkalian antara arus $(\mathrm{Im})$ dan tegangan $(\mathrm{Vm})$. Arus dan tegangan maksimum terjadi pada saat sel surya menghasilkan daya maksimum. 


\section{Arus Short Circuit (Isc) dan Tegangan Open Circuit (Voc)}

Arus short circuit atau arus hubung singkat (Isc) merupakan arus yang melalui sel surya saat tegangan yang melalui sel surya bernilai nol atau ketika beban dihubung singkat. Arus ini disebabkan oleh proses generation dan pengumpulan dari carrier yang dihasilkan dari iluminasi cahaya matahari. Kurva I-V yang menunjukkan arus short circuit diperlihatkan pada gambar 13.

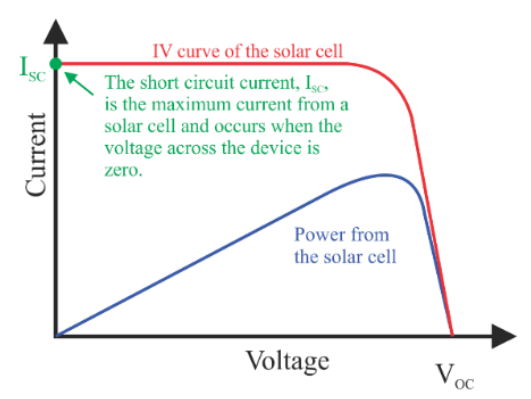

\section{Gambar 13 Kurva I-V Menunjukkan Arus Short Circuit}

Arus short circuit berbanding lurus terhadap intensitas cahaya matahari yang menyinari permukaan divais. Arus short circuit ini dipengaruhi oleh beberapa faktor, yaitu:

1. Jumlah foton.

2. Luas area sel surya.

3. Spektrum cahaya yang diterima.

4. Karakteristik optik.

5. Probabilitas pengumpulan iluminasi.

Tegangan open circuit atau tegangan pada saat rangkaian terbuka merupakan tegangan maksimum yang dihasilkan divais sel surya yang terjadi pada saat arus sebesar nol amper. Kurva I-V yang menunjukkan tegangan open circuit dijelaskan pada gambar 14:

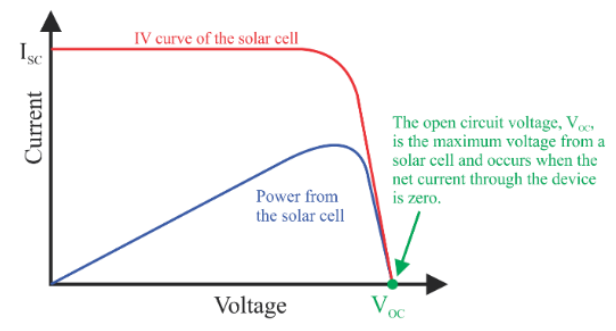

Gambar 14 Kurva I-V Menunjukkan Tegangan Open Circuit

Berdasarkan grafik diatas, Voc meningkat secara logaritmis terhadap kenaikan intensitas cahaya matahari.

\section{Fill Factor}

Fill Factor merupakan parameter yang berfungsi untuk menentukan daya maksimum dari sel surya dalam kaitannya dengan Voc dan Isc. 


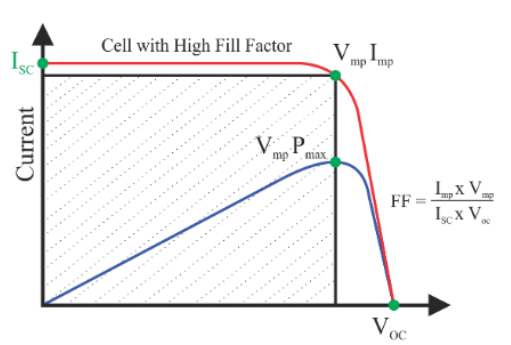

Gambar 15 Titik Daya, Tegangan, dan Arus Maksimum pada Kurva I-V Sel Surya untuk Menunjukkan Fill Factor

FF akan menentukan besarnya daya maksimum yang dapat dihasilkan oleh suatu divais, sehingga akan menentukan besarnya arus dan tegangan maksimum power point. Pada gambar 15 terlihat bahwa daerah yang dibentuk oleh VmIm lebih kecil daripada daerah yang dibentuk oleh VocIsc. Perbandingan inilah yang disebut dengan fill factor.

\section{Karaktersitik Efisiensi Energi}

Efisiensi konversi merupakan perbandingan antara daya yang dapat diperoleh sebuah sel surya dengan daya yang diterima dari cahaya matahari.

$$
\eta=\frac{\boldsymbol{P}_{\mathrm{m}}}{\boldsymbol{P}_{\mathrm{ln}}}
$$

\section{Rangkaian Seri dan Paralel Sel Surya}

Bila sel surya dihubungkan seri maka tegangan yang dibangkitkan akan semakin besar tetapi arus yang dibangkitkan tetap, sedangkan jika dihubungkan paralel maka arus yang dibangkitkan akan semakin besar tetapi tegangan yang dibangkitkan tetap. [ ${ }^{\text {S. Pewarna.2009] }}$

\section{Konfigurasi Sel Surya}

Pada umumnya sel surya dikonfigurasikan satu dengan lainnya baik secara hubungan seri ataupun secara paralel untuk membentuk suatu rangkaian sel surya yang disebut "Modul Sel Surya". Beberapa modul sel surya dihubungkan seri atau paralel untuk membentuk satu rangkaian yang disebut "Panel Sel Surya", sedangkan jika modul sel surya dihubungkan secara baris dan kolom disebut "Array Sel Surya".

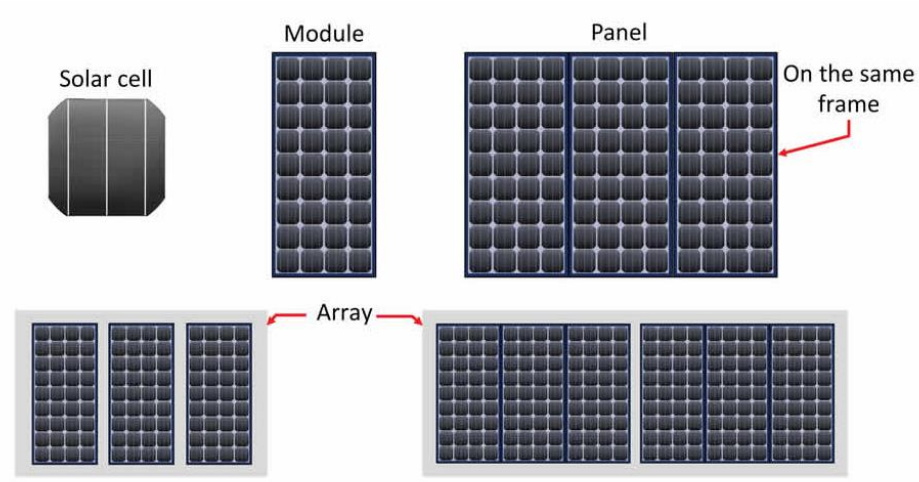

Gambar 16 Bentuk Sel, Modul/Panel dan Array Dari Sel Surya. 


\subsection{Kincir Angin}

Kincir angin adalah sebuah alat yang berfungsi untuk mengkonversi energi angin menjadi energi mekanis. Kincir angin yang digunakan untuk menghasilkan sebuah energi listrik disebut dengan turbin angin (Wind Turbine). Turbin angin mampu mengubah energi angin menjadi energi mekanik dengan memanfaatkan putaran kincir untuk memutar generator sehingga akan dihasilkan energi listrik.

\section{Kincir Angin Sumbu Horizontal}

Kincir angin sumbu horizontal atau Horizontal Axis Wind Turbine (HAWT) adalah kincir angin yang mempunyai poros yang sejajar dengan tanah dan arah poros utama sesuai dengan arah datangnya angin. Poros kincir dapat berputar $360^{\circ}$ terhadap sumbu vertikal untuk menyesuaikan arah angin. Terdapat beberapa jenis kincir angin poros horizontal diantaranya ditunjukkan pada gambar 17

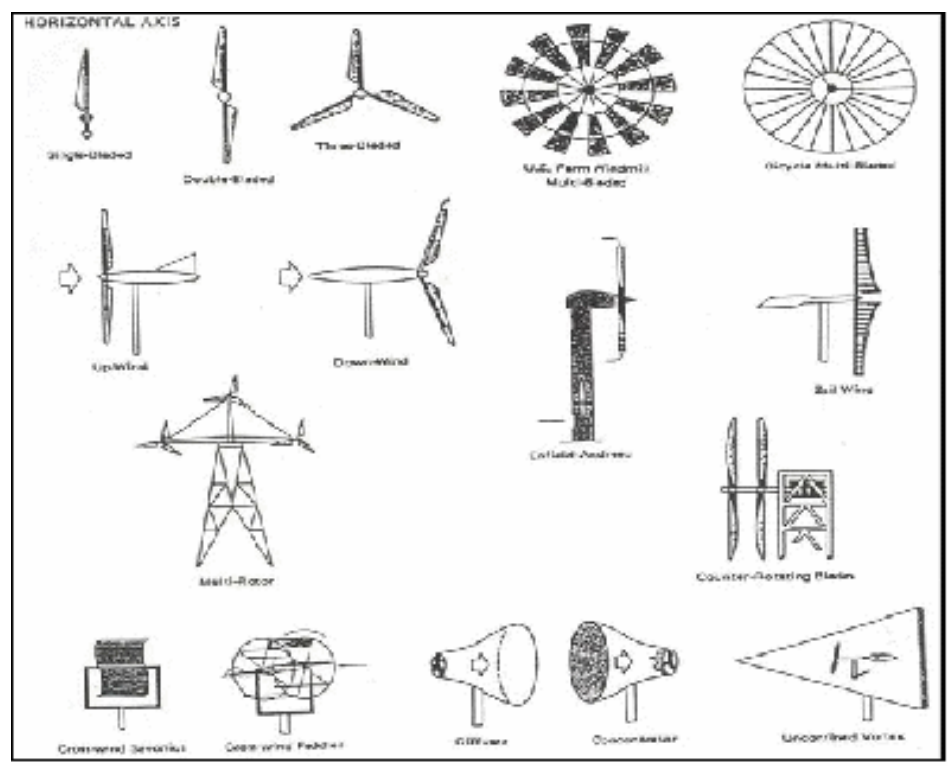

Gambar 17 KincirAngin Sumbu Horizontal

Tabel 1 Kelebihan dan Kekurangan Kincir Angin Sumbu Horizontal.

\begin{tabular}{|c|c|}
\hline Kelebihan & Kekurangan \\
\hline $\begin{array}{l}\text { 1. Efisiensi lebih tinggi, karena } \\
\text { sudu selalu bergerak tegak lurus } \\
\text { terhadap arah angin. } \\
\text { 2. Dapat dibuat dengan } \\
\text { kemampuan pitch control untuk } \\
\text { sudu-sudunya. }\end{array}$ & $\begin{array}{l}\text { 1. Membutuhkan konstruksi } \\
\text { tower yang tinggi. } \\
\text { 2. Memerlukan yaw control } \\
\text { untuk mengarahkan sudu ke arah } \\
\text { angin }\end{array}$ \\
\hline
\end{tabular}

\section{Kincir Angin Sumbu Vertikal}

Kincir angin sumbu vertikal atau Vertical Axis Wind Turbine (VAWT) adalah kincir angin yang memiliki poros tegak lurus dengan tanah atau arah datangnya angin. 


\subsection{Battery Control Unit}

BCU adalah peralatan elektronik yang digunakan untuk mengatur arus searah yang diisi ke baterai dan diambil dari baterai ke beban. BCU mengatur over charging (kelebihan pengisian baterai karena kondisi baterai sudah penuh) dan kelebihan tegangan dari panel surya, kelebihan tegangan dan pengisian akan mengurangi umur baterai. BCU adalah teknologi Pulse Width Modulation (PWM) untuk mengatur fungsi pengisian baterai dan penyaluran arus dari baterai ke beban. Untuk menggunakan BCU ada yang harus diperhatikan, sebagai berikut:

- Tegangan 12 Volt DC / 24 Volt DC.

- Kemampuan (dalam arus searah) dari BCU. Misalnya 5 Ampere, 6 Ampere, 10 Ampere dan sebagainya. Dengan catatan kapasitas arus BCU harus lebih besar dari arus panel surya ${ }^{[5]}$, secara matematis dapat ditulis sebagai berikut:

$$
I_{B C U}>I_{\text {Maks Panel }}
$$

$\mathrm{I}_{\mathrm{BCU}} \quad=$ Kapasitas arus BCU.

$\mathrm{I}_{\text {Maks Panel }}=$ Arus maksismum yang dibangkitkan panel surya.

\subsection{Inverter}

Inverter adalah seperangkat alat yang merupakan rangkaian komponen elektronika yang digunakan untuk mengubah arus DC (Direct Curent) menjadi arus AC (Alternating Curent). Beberapa hal yang perlu dipertimbangkan dalam pemilihan inverter:

- Gunakan inverter yang beban kerjanya mendekati dengan beban yang hendak kita gunakan agar efisiensi kerjanya maksimal.

- Input DC 12 Volt atau 24 Volt.

- Sinewave atau square wave output AC.

Efisiensi dari inverter $^{[5]}$, sebagai berikut:

$$
\eta=\frac{P o}{P i} \times 100 \%
$$

$$
\begin{array}{ll}
\mathrm{Po} & =\text { Daya output aktif (Watt). } \\
\mathrm{Pi} & =\text { Daya input (Watt). } \\
\eta & =\text { Efisiensi inverter. }
\end{array}
$$

Inverter yang berhubungan langsung dengan beban listrik mempunyai kapasitas kerja dalam satuan Watt. Penentuan kapasitas inverter harus lebih besar dari beban maksimum yang dibebani $^{[5]}$. Secara matematis ditulis:

$$
P_{\text {inv }}>P_{\text {maks load }}
$$

$\mathrm{P}_{\text {inv }} \quad=$ Daya maksimum inverter (Watt).

$\mathrm{P}_{\text {maks load }}=$ Daya maksimum beban $($ Watt $)$. 


\subsection{Baterai}

Baterai adalah sebuah alat yang digunakan untuk menyimpan tenaga listrik yang dihasilkan dari pembangkit tenaga surya sehingga bisa digunakan kapan saja selama dibutuhkan. Kapasitas baterai adalah jumlah Ampere Jam (Ah = Kuat Arus/Ampere x Waktu/Hour), artinya baterai dapat memberikan atau menyuplai sejumlah isinya secara rata-rata sebelum tiap selnya menyentuh tegangan turun (drop voltage) yaitu sebesar 1,75 Volt (tiap sel memiliki tegangan sebesar 2 Volt, jika dipakai maka tegangan akan terus turun dan kapasitas efektif dikatakan sudah terpakai semuanya bila tegangan sel menyentuh 1,75 Volt), dalam kondisi ini baterai harus diisi ulang. ${ }^{\text {P. Togan.2009][ D. Perlanda.2018] }}$

Depth of Discharge (DOD), adalah suatu ketentuan yang membatasi tingkat kedalaman discharge maksimum yang dapat diberlakukan pada baterai tersebut. Pengaturan DOD berperan dalam menjaga usia pakai (life time) dari baterai tersebut. Berikut ini adalah tabel yang menunjukkan hubungan antara DOD dan usia pakai dari suatu baterai. ${ }^{\text {Mario Roal.2015] }}$

Tabel 2 Hubungan Antara DOD dan Usia Pakai Baterai.

\section{Depth of Discharge Usia Baterai}

\begin{tabular}{cc} 
(DOD) & $($ Cycle $)$ \\
\hline $10 \%$ & 6200 \\
\hline $20 \%$ & 5200 \\
\hline $30 \%$ & 4400 \\
\hline $40 \%$ & 3700 \\
\hline $50 \%$ & 3000 \\
\hline $60 \%$ & 2400 \\
\hline $70 \%$ & 2000 \\
\hline $80 \%$ & 1600 \\
\hline
\end{tabular}

Perhitungan kapasitas baterai (battery capacity), untuk menjamin kontinuitas suplai energi. Untuk menentukan berapa kapasitas daya baterai yang akan digunakan, sebagai berikut:

$$
\mathrm{P}_{\text {baterai }}=\mathrm{V} \mathrm{X} \mathrm{I}
$$

$\mathrm{P}_{\text {baterai }}=$ Daya Baterai (Watt/hour).

$\mathrm{V} \quad=$ Tegangan Baterai (Volt).

I $\quad=$ Arus Baterai (Ah).

Sedangkan untuk menentukan berapa lama baterai mampu menyuplai energi listrik, sebagai berikut:

$$
\mathrm{I}_{\mathrm{BC}}=\frac{\mathrm{P}}{\mathrm{V}}
$$

$\mathrm{I}_{\mathrm{BC}} \quad=$ Kapasitas Baterai (Ah).

$\mathrm{P} \quad=$ Daya $($ Watt $)$.

$\mathrm{V} \quad=$ Tegangan Baterai (Volt). 
Untuk menentukan kapasitas baterai menggunakan ketentuan DOD, sebagai berikut:

$$
\mathrm{I}_{\mathrm{BCDOD}}=\frac{\mathrm{IBC}}{\mathrm{DOD}}
$$

$\mathrm{I}_{\mathrm{BCDOD}}=$ Kapasitas baterai ketentuan DOD (Ah).

$\mathrm{I}_{\mathrm{BC}} \quad=$ Kapasitas Baterai $(\mathrm{Ah})$.

DOD = Depth of Discharge.

\section{Metodologi Penelitian}

\subsection{Studi Literatur}

Studi literatur adalah proses pencarian informasi serta referensi dari semua aspek yang berhubungan dengan rancang bangun pembangkit listrik portable tenaga surya dan angin dengan sistem hybrid untuk tempat pengungsian bencana alam. Adapun yang perlu dikaji serta dicari sebagai referensi adalah sebagai berikut:

- Karakteristik dan prinsip kerja komponen utama.

- Karakteristik dan prinsip kerja komponen pendukung.

\subsection{Perancangan Pembuatan Alat}

\section{Alat dan Bahan}

Dalam penelitian ini digunakan berbagai jenis bahan, mulai dari bahan utama sampai dengan komponen pendukung, serta alat pendukung untuk penyelesaian dalam pembuatan mulai dari perancangan sampai finishing. Adapun alat dan bahan yang digunakan tersebut adalah sebagai berikut:

\section{Komponen Utama}

Pada bagian ini terdapat komponen yang paling utama, komponen ini adalah komponen yang berfungsi untuk membangkitkan energi listrik dan menyimpan energi listrik. Adapun komponen-komponen tersebut adalah sebagai berikut:

Tabel 3 Daftar Komponen Utama

\begin{tabular}{ll}
\hline No & \multicolumn{1}{c}{ Nama } \\
\hline 1 & Photovoltaic (Panel Surya) \\
\hline 2 & Wind Turbine \\
\hline 3 & Baterai \\
\hline
\end{tabular}

\section{Komponen Pendukung}

Pada bagian ini terdapat komponen pendukung yaitu komponen elektronika. Komponen elektronika berfungsi untuk mendukung sistem kerja dari pembangkit listrik. Adapun komponen-komponen tersebut adalah sebagai berikut: 


\section{Tabel 4 Daftar Komponen Pendukung}

\begin{tabular}{ll}
\hline No & \multicolumn{1}{c}{ Nama } \\
\hline 1 & Battery Control Unit \\
\hline 2 & Inverter \\
\hline 3 & Tempat Fuse \\
\hline 4 & Fuse \\
\hline 5 & MCB (Miniature Circuit Breaker) \\
\hline 6 & Terminal Blok \\
\hline 7 & Switch \\
\hline 8 & Relay \\
\hline 9 & Stop Kontak \\
\hline 10 & Kabel \\
\hline 11 & Baterai Level Meter \\
\hline
\end{tabular}

\section{Prinsip Kerja}

Photovoltaic berguna sebagai penyerap energi matahari yang nantinya akan menghasilkan energi listrik berupa tegangan DC (Direct Current). Wind generator berguna sebagai pembangkit listrik yang merubah tenaga bayu menjadi energi listrik berupa arus DC. Kemudian arus listrik dari kedua sumber pembangkitan ini di hubungkan ke rangkaian solar / battery charge controller dan listrik digunakan untuk mengisi baterai.

Outputan dari solar/battery charge controller akan dihubungkan ke stop kontak 12 V DC dan ke inverter guna mengkonversi arus DC menjadi arus AC (Alternating Current). Setelah itu tegangan $220 \mathrm{~V}$ AC di salurkan melalui stop kontak $220 \mathrm{~V}$ AC.

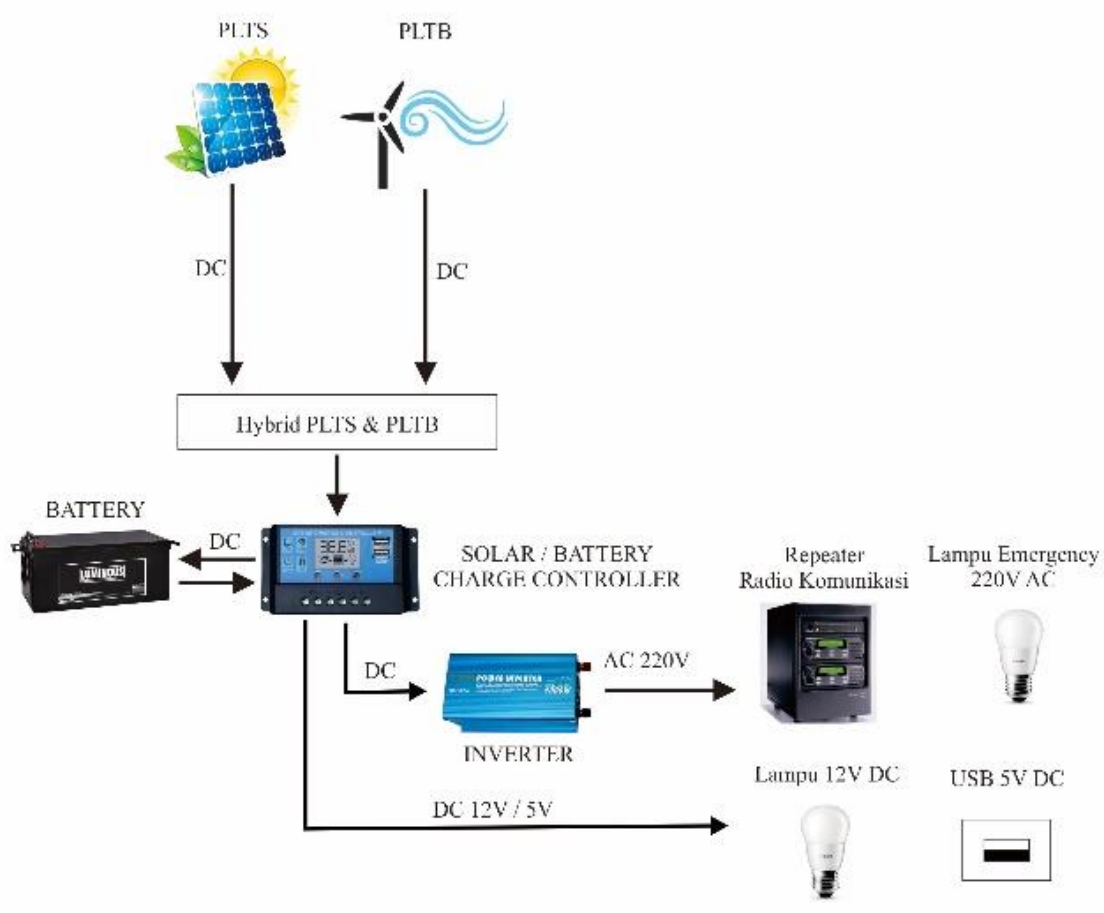

Gambar 18 Skema Rancang Bangun Pembangkit Listrik Portable Tenaga Surya dan Angin Sistem Hybrid untuk Tempat Pengungsian Bencana Alam. 


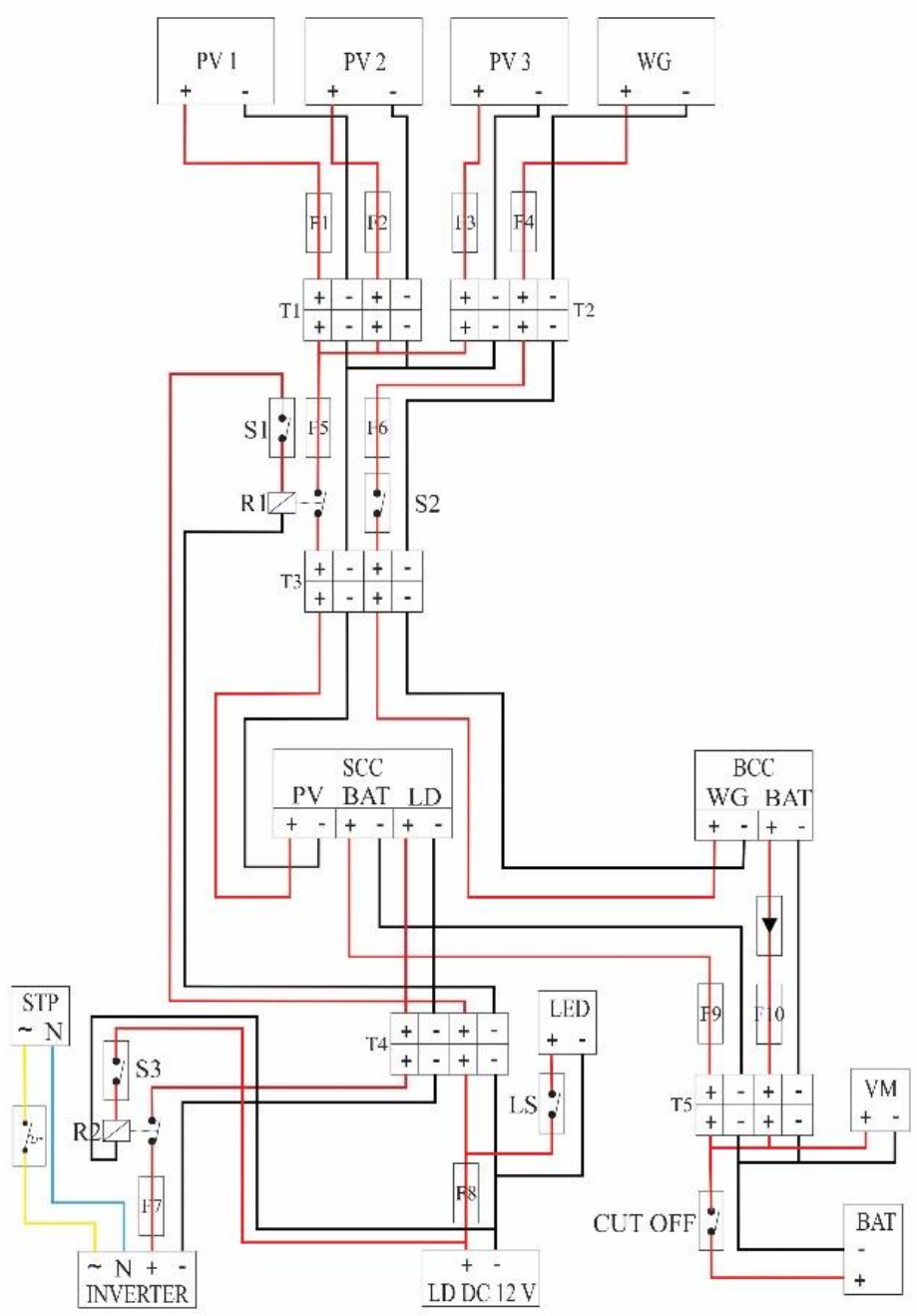

Gambar 19 Diagram Alur Kabel Rancang Bangun Pembangkit Listrik Portable Tenaga Surya dan Angin Sistem Hybrid untuk Tempat Pengungsian Bencana Alam.

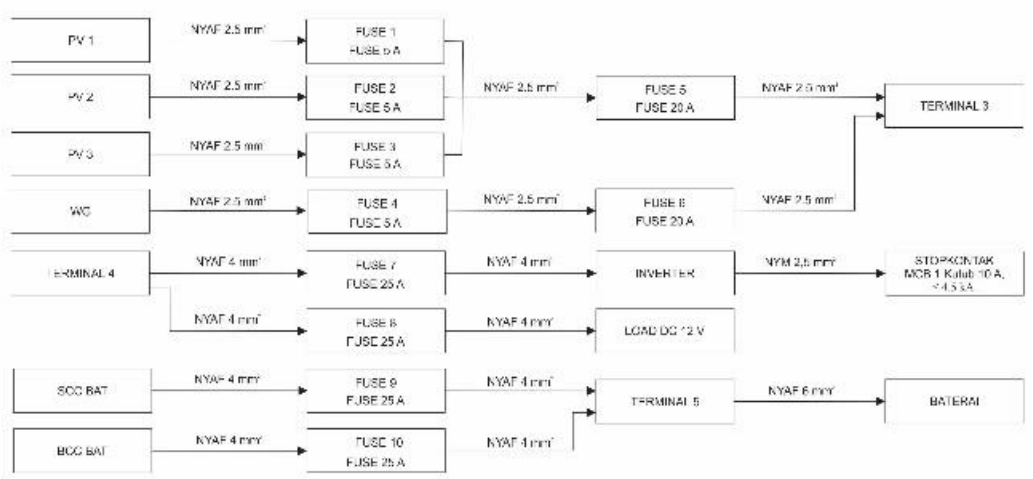

Gambar 20 Diagram Protekssi Rancang Bangun Pembangkit Listrik Portable Tenaga Surya dan Angin Sistem Hybrid untuk Tempat Pengungsian Bencana Alam. 


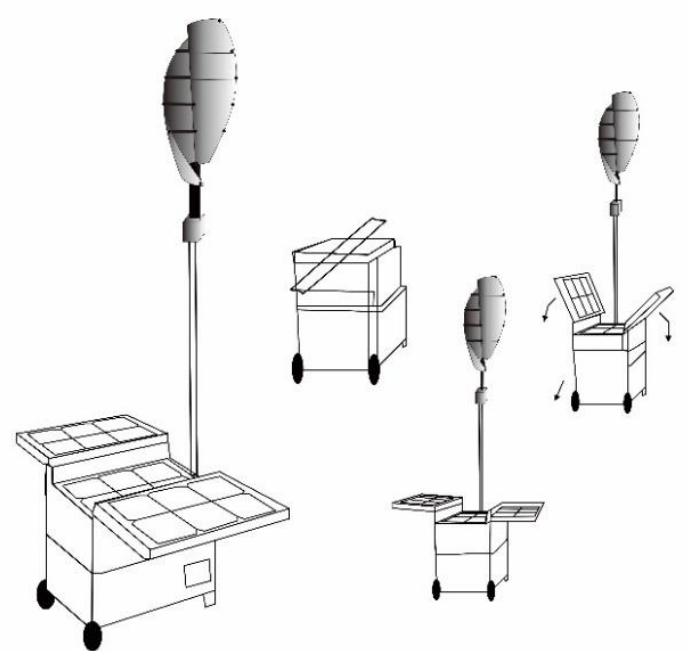

Gambar 21 Konsep Box Rancang Bangun Pembangkit Listrik Portable Tenaga Surya dan Angin Sistem Hybrid untuk Tempat Pengungsian Bencana Alam.

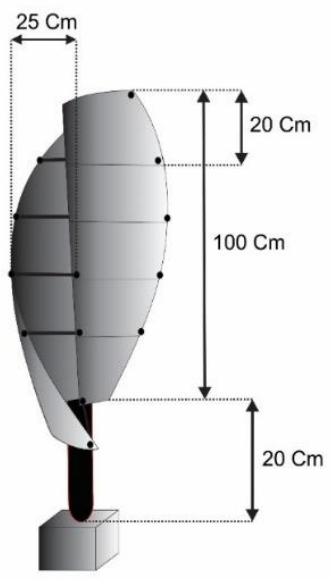

Gambar 22 Blade Wind Turbin Rancang Bangun Pembangkit Listrik Portable Tenaga Surya dan Angin Sistem Hybrid untuk Tempat Pengungsian Bencana Alam.

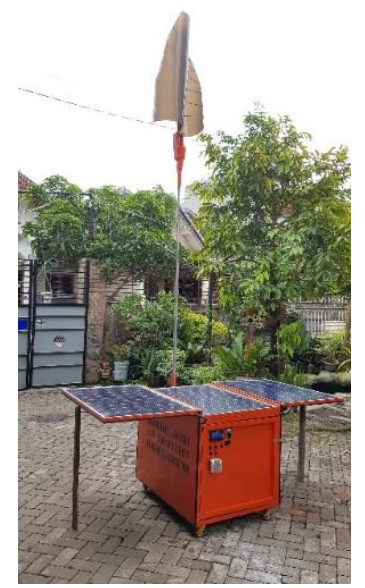

Gambar 23 Pembangkit Listrik Portable Tenaga Surya dan Angin Sistem Hybrid untuk Tempat Pengungsian Bencana Alam 


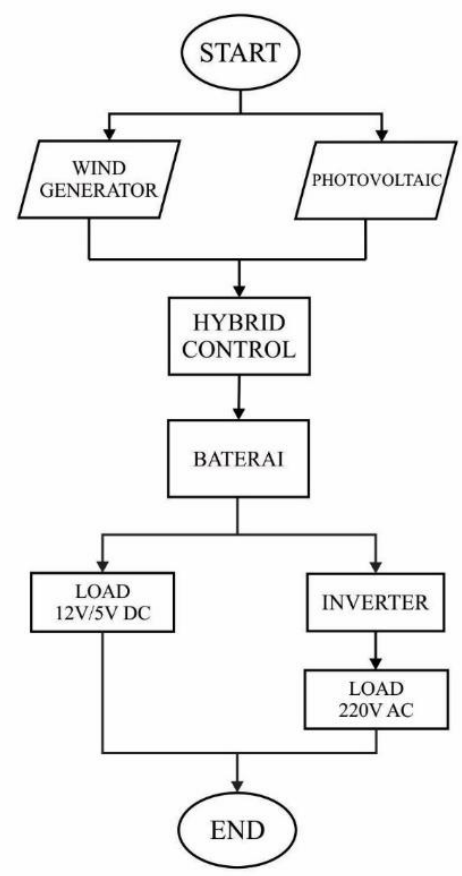

Gambar 24 Flowchart Rancang Bangun Pembangkit Listrik Portable Tenaga Surya dan Angin Sistem Hybrid untuk Tempat Pengungsian Bencana Alam.

\subsection{Pelaksanaan Penelitian}

Pennelitian dalam pembuatan rancang bangun alat ini dilakukan di beberapa tempat yaitu:

- Lokasi tempat yang luas dan terbuka, penelitian dilakukan di lapangan yang luas dan terbuka kurang lebih selama 1 minggu (7 Hari). Tujuan penelitian ini dilakukan untuk mengetahui secara langsung proses pembangkitan listrik yang dihasilkan.

- Laboratorium Renewable Energy Teknik Elektro S-1 ITN Malang. Tempat penelitian kedua dilakukan di Laboratorium Renewable Energy Teknik Elektro S-1 ITN. Waktu penelitian dilakukan selama proses pembuatan alat berlangsung sampai dengan selesai, penelitian dilakukan berdasarkan proses kerja alat.

\section{Analisis Hasil dan Data}

\subsection{Hasil Data Pengukuran Solar Cell}

Tabel 5 Data Pengukuran Solar Cell

\begin{tabular}{|c|c|c|c|c|c|c|c|c|c|}
\hline \multirow{2}{*}{ Jam } & \multirow{2}{*}{ Cuaca } & \multicolumn{2}{|c|}{ Solar Cell 1} & \multicolumn{2}{|c|}{$\begin{array}{c}\text { Solar Cell } \\
2\end{array}$} & \multicolumn{2}{|c|}{$\begin{array}{c}\text { Solar Cell } \\
3\end{array}$} & \multicolumn{2}{|c|}{ Paralel } \\
\hline & & $\begin{array}{l}\text { Arus } \\
\text { (I) }\end{array}$ & $\begin{array}{c}\text { Tegangan } \\
\text { (V) }\end{array}$ & (I) & (V) & (I) & (V) & (I) & (V) \\
\hline 10:00 & Mendung & 0,5 & 18 & 0,5 & 18 & 0,5 & 18 & 1,8 & 18 \\
\hline 11:00 & Cerah & 1,16 & 20 & 1,16 & 20 & 1,16 & 20 & 4,2 & 20 \\
\hline 12:00 & Cerah & 1,16 & 20 & 1,16 & 20 & 1,16 & 20 & 4,2 & 20 \\
\hline 13:00 & Cerah & 1,16 & 20 & 1,16 & 20 & 1,16 & 20 & 4,2 & 20 \\
\hline 14:00 & Cerah & 1,16 & 20 & 1,16 & 20 & 1,16 & 20 & 4,2 & 20 \\
\hline 15:00 & Mendung & 0,5 & 18 & 0,5 & 18 & 0,5 & 18 & 1,8 & 18 \\
\hline 16:00 & Mendung & 0,5 & 18 & 0,5 & 18 & 0,5 & 18 & 1,8 & 18 \\
\hline
\end{tabular}




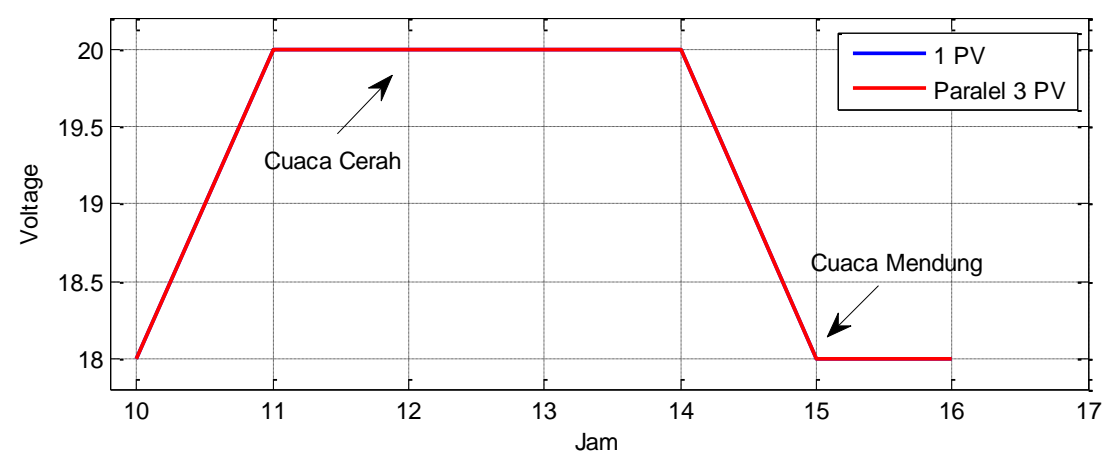

Gambar 25 Data Pengukuran Tegangan Pada Solar Cell

Berdasarkan gambar 25 dapat dilihat bahwa intensitas cahaya matahari (Cuaca) mempengaruhi tegangan pada solar cell. Pada jam 11:00 sampai dengan jam 14:00 nilai tegangan yang dihasilkan mencapai 20 Volt, sedangkan pada jam 15:00 sampai dengan 16:00 nilai tegangan yang dihasilkan 18 Volt. Semakin banyak cahaya matahari yang diperoleh maka semakin besar nilai tegangan yang dihasilkan. Pada rangkaian paralel tegangan tidak berubah (Sama dengan tidak diparalel).

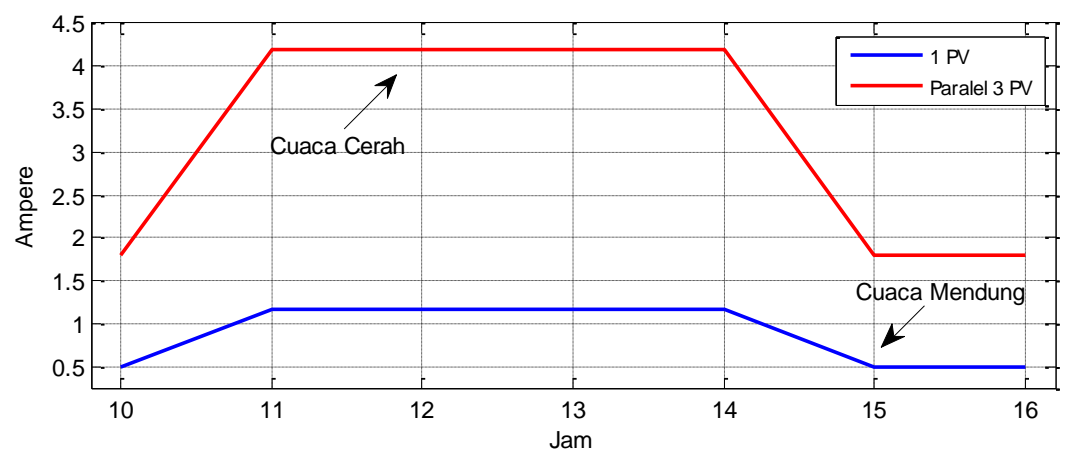

Gambar 26 Data Pengukuran Arus Pada Solar Cell

Berdasarkan gambar 26 dapat dilihat bahwa intensitas cahaya matahari (Cuaca) dan jenis hubungan paralel mempengaruhi arus pada solar cell. Pada jam 11:00 sampai dengan jam 14:00 nilai arus yang dihasilkan pada hubungan tanpa paralel mencapai 1,16 Amper, jam 15:00 sampai dengan 16:00 nilai arus yang dihasilkan pada hubungan tanpa paralel 0,5 Amper. Sedangkan jika dihubungkan paralel nilai arus yang dihasilkan pada jam 11 sampai dengan jam 14:00 adalah 20 Amper, sangat terlihat jelas untuk peningkatan nilai arus.

\subsection{Hasil Data Pengukuran Wind Turbine}

Tabel 6 Data Pengukuran Wind Generator

\begin{tabular}{cc}
\hline \multicolumn{2}{c}{ Wind Turbin } \\
\hline $\begin{array}{c}\text { Kecepatan Generator } \\
(\mathbf{R p m})\end{array}$ & Tegangan $(\mathbf{V}) \mathbf{D C}$ \\
\hline 150 & 10 \\
180 & 12 \\
210 & 14 \\
240 & 16 \\
270 & 18 \\
300 & 20 \\
330 & 22 \\
360 & 24 \\
\hline
\end{tabular}




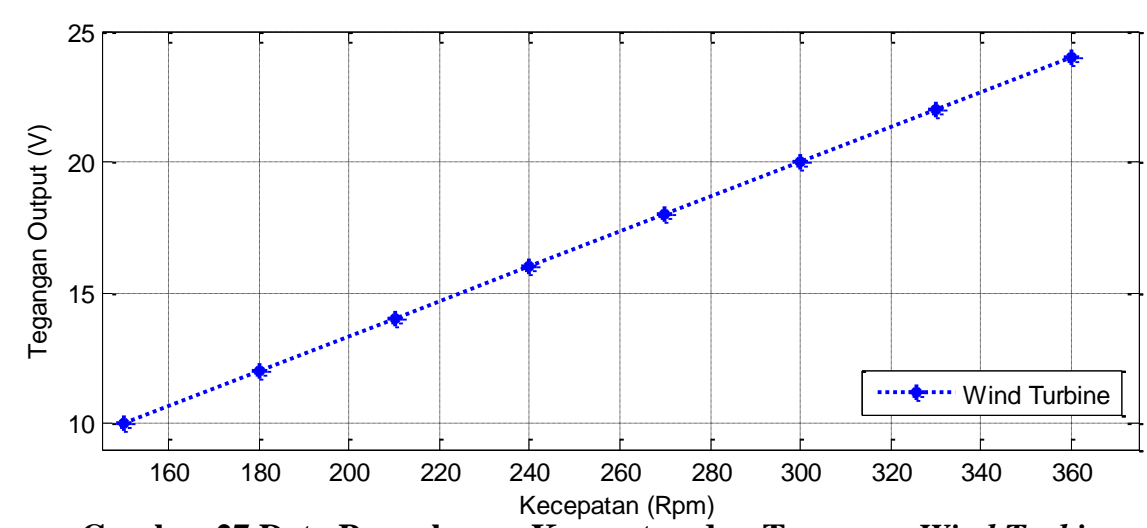

Gambar 27 Data Pengukuran Kecepatan dan Tegangan Wind Turbine

Berdasarkan grafik 3 dapat dilihat bahwa kecepatan generator mempengaruhi nilai tegangan yang dihasilkan. Pada kecepatan $150 \mathrm{Rpm}$ nilai tegangan yang dihasilkan 10 Volt DC, sedangkan pada kecepatan 360 Rpm nilai tegangan yang dihasilkan mencapai 24 Volt DC. Generator ini bisa disebut dengan generator rpm rendah, dimana hanya memerlukan kecepatan yang pelan untuk menghasilkan tegangan normal DC yaitu 12 Volt.

\subsection{Hasil Data Pengukuran Tegangan dan Arus Pada Inverter}

Tabel 7 Data Pengukuran Tegangan dan Arus Pada Inverter

\begin{tabular}{|c|c|c|c|c|c|c|}
\hline \multirow{4}{*}{ Jam } & \multicolumn{6}{|c|}{ Inverter } \\
\hline & \multicolumn{6}{|c|}{ Daya (Watt) } \\
\hline & \multicolumn{3}{|c|}{0} & \multicolumn{3}{|c|}{40} \\
\hline & Cuaca & $\begin{array}{l}\text { Arus } \\
\text { (I) }\end{array}$ & $\begin{array}{c}\text { Tegangan } \\
\text { (V) }\end{array}$ & Cuaca & $\begin{array}{c}\text { Arus } \\
\text { (I) }\end{array}$ & $\begin{array}{c}\text { Tegangan } \\
\text { (V) }\end{array}$ \\
\hline $10: 00$ & - & 0 & 235 & Cerah & 0,1 & 233 \\
\hline $11: 00$ & - & 0 & 235 & Cerah & 0,1 & 230 \\
\hline $12: 00$ & - & 0 & 235 & Cerah & 0,1 & 230 \\
\hline $13: 00$ & - & 0 & 235 & Cerah & 0,1 & 229 \\
\hline $14: 00$ & - & 0 & 235 & Mendung & 0,1 & 226 \\
\hline $15: 00$ & - & 0 & 235 & Cerah & 0,1 & 226 \\
\hline $16: 00$ & - & 0 & 235 & Mendung & 0,1 & 224 \\
\hline $17: 00$ & - & 0 & 235 & Mendung & 0,1 & 223 \\
\hline 18:00 & - & 0 & 235 & Malam & 0,1 & 222 \\
\hline 19:00 & - & 0 & 235 & Malam & 0,1 & 221 \\
\hline 20:00 & - & 0 & 235 & Malam & 0,1 & 221 \\
\hline 21:00 & - & 0 & 235 & Malam & 0,1 & 220 \\
\hline $22: 00$ & - & 0 & 235 & Malam & 0,1 & 220 \\
\hline $23: 00$ & - & 0 & 235 & Malam & 0,1 & 219 \\
\hline 0:00 & - & 0 & 235 & Malam & 0,1 & 218 \\
\hline 1:00 & - & 0 & 235 & Malam & 0,1 & 217 \\
\hline $2: 00$ & - & 0 & 235 & - & - & - \\
\hline 3:00 & - & 0 & 235 & - & - & - \\
\hline 4:00 & - & 0 & 235 & - & - & - \\
\hline 5:00 & - & 0 & 235 & - & - & - \\
\hline $6: 00$ & - & 0 & 235 & - & - & - \\
\hline 7:00 & - & 0 & 235 & - & - & - \\
\hline $8: 00$ & - & 0 & 235 & - & - & - \\
\hline 9:00 & - & 0 & 235 & - & - & - \\
\hline
\end{tabular}




\begin{tabular}{|c|c|c|c|c|c|c|}
\hline \multirow{4}{*}{ Jam } & \multicolumn{6}{|c|}{ Inverter } \\
\hline & \multicolumn{6}{|c|}{ Daya (Watt) } \\
\hline & \multicolumn{3}{|c|}{100} & \multicolumn{3}{|c|}{140} \\
\hline & Cuaca & (I) & $(\mathrm{V})$ & Cuaca & (I) & $(\mathrm{V})$ \\
\hline $10: 00$ & Cerah & 0,4 & 226 & Cerah & 0,6 & 219 \\
\hline $11: 00$ & Cerah & 0,4 & 226 & Mendung & 0,6 & 216 \\
\hline $12: 00$ & Cerah & 0,4 & 227 & Mendung & 0,6 & 210 \\
\hline $13: 00$ & Cerah & 0,4 & 225 & Mendung & 0,6 & 205 \\
\hline $14: 00$ & Cerah & 0,4 & 220 & Cerah & 0,6 & 207 \\
\hline $15: 00$ & Mendung & 0,4 & 217 & Mendung & 0,6 & 192 \\
\hline $16: 00$ & Mendang & 0,4 & 210 & - & - & - \\
\hline $17: 00$ & Mendung & 0,4 & 200 & & & \\
\hline $18: 00$ & - & - & - & & & \\
\hline 19:00 & - & - & - & & & \\
\hline 20:00 & - & - & - & & & \\
\hline $21: 00$ & - & - & - & & & \\
\hline $22: 00$ & - & - & - & & & \\
\hline $23: 00$ & - & - & - & & & \\
\hline $0: 00$ & - & - & - & & & \\
\hline 1:00 & - & - & - & & & \\
\hline $2: 00$ & - & - & - & & & \\
\hline $3: 00$ & - & - & - & & & \\
\hline $4: 00$ & - & - & - & & & \\
\hline $5: 00$ & - & - & - & & & \\
\hline 6:00 & - & - & - & & & \\
\hline $7: 00$ & - & - & - & & & \\
\hline 8:00 & - & - & - & & & \\
\hline $9: 00$ & - & - & - & & & \\
\hline
\end{tabular}

\begin{tabular}{|c|c|c|c|c|c|c|}
\hline \multirow{4}{*}{ Jam } & \multicolumn{6}{|c|}{ Inverter } \\
\hline & \multicolumn{6}{|c|}{ Daya (Watt) } \\
\hline & \multicolumn{3}{|c|}{200} & \multicolumn{3}{|c|}{240} \\
\hline & Cuaca & $\begin{array}{l}\text { Arus } \\
\text { (I) }\end{array}$ & Cuaca & Cuaca & $\begin{array}{l}\text { Arus } \\
\text { (I) }\end{array}$ & $\begin{array}{c}\text { Tegangan } \\
\text { (V) }\end{array}$ \\
\hline $10: 00$ & Cerah & 0,9 & Cerah & Cerah & 0,9 & 216 \\
\hline $11: 00$ & Cerah & 0,8 & Cerah & Cerah & 0,8 & 206 \\
\hline $12: 00$ & Cerah & 0,8 & Cerah & Cerah & 0,8 & 205 \\
\hline $13: 00$ & Mendung & 0,8 & Mendung & Mendung & 0,8 & 192 \\
\hline $14: 00$ & Cerah & 0,8 & Cerah & Cerah & 0,8 & 197 \\
\hline $15: 00$ & Mendung & 0,8 & Mendung & Mendung & 0,8 & 192 \\
\hline $16: 00$ & Mendung & 0,8 & Mendung & Mendung & 0,8 & 192 \\
\hline $17: 00$ & - & - & - & - & - & - \\
\hline 18:00 & - & - & - & - & - & - \\
\hline 19:00 & - & - & - & - & - & - \\
\hline 20:00 & - & - & - & - & - & - \\
\hline $21: 00$ & - & - & - & - & - & - \\
\hline $22: 00$ & - & - & - & - & - & - \\
\hline 23:00 & - & - & - & - & - & - \\
\hline 0:00 & - & - & - & - & - & - \\
\hline $1: 00$ & - & - & - & - & - & - \\
\hline 2:00 & - & - & - & - & - & - \\
\hline 3:00 & - & - & - & - & - & - \\
\hline 4:00 & - & - & - & - & - & - \\
\hline 5:00 & - & - & - & - & - & - \\
\hline 6:00 & - & - & - & - & - & - \\
\hline 7:00 & - & - & - & - & - & - \\
\hline 8:00 & - & - & - & - & - & - \\
\hline 9:00 & - & - & - & - & - & - \\
\hline
\end{tabular}




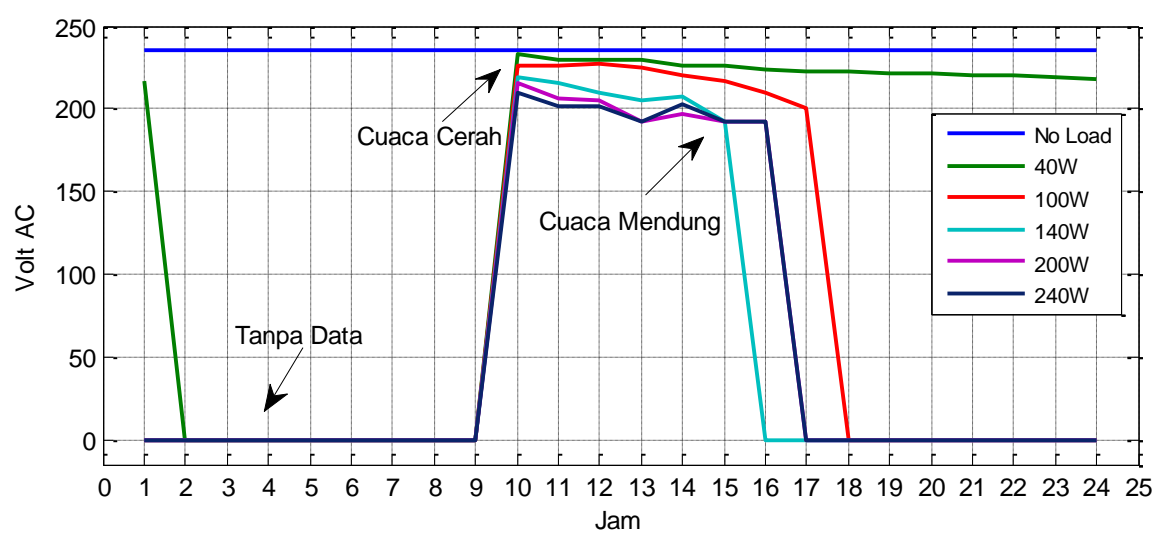

Gambar 28 Data Pengukuran Tegangan dan Arus Pada Inverter

Berdasarkan grafik 4 dapat dilihat bahwa nilai beban dan cuaca dapat mempengaruhi tegangan output pada inverter yang digunakan. Pada nilai beban 240 Watt nilai tegangan yang dihasilkan oleh inverter sebesar 219 Volt pada jam 10:00 dengan cuaca cerah dan 192 Volt pada jam 15:00 dengan cuaca mendung. Sedangkan, pada nilai beban 40 Watt nilai tegangan yang dihasilkan oleh inverter lebih stabil sebesar 233 Volt pada jam 10:00 dengan cuaca cerah dan 226 Volt pada jam 15:00 dengan cuaca cerah. Semakin besar nilai beban yang digunakan semakin cepat habis kapasitas baterai yang dimiliki, pada beban 240 Watt mampu bertahan selama 6 jam dengan fluktuasi cuaca sedangkan pada beban 40 Watt mampu bertahan selama 16 jam dengan fluktuasi cuaca.

Perhitungan Kapasitas Baterai

$\mathrm{P}_{\text {baterai }}=12 \mathrm{~V} \times 100 \mathrm{Ah}$

$\mathrm{P}_{\text {baterai }}=1200 \mathrm{Wh}$

Perhitungan Kapasitas Baterai Berdasarkan Beban

$\mathrm{I}_{\mathrm{BC}} \quad=\frac{50 \mathrm{~W}}{12 \mathrm{~V}}$

$\mathrm{I}_{\mathrm{BC}}=4,16 \mathrm{Ah}$

Perhitungan Kapasitas Baterai Berdasarkan Beban dan DOD

$\mathrm{I}_{\mathrm{BCDOD}}=\frac{4,16 \mathrm{Ah}}{0,8}$

$\mathrm{I}_{\mathrm{BCDOD}}=5,2 \mathrm{Ah}$

Berdasarkan perhitungan diatas, dengan baterai berkapasitas 100 Ah mampu menyuplai beban 50 Watt selama 19,23 Jam. Jika, dengan beban 500 Watt maka hanya mampu selama 1,9 Jam. Beban 500 Watt dapat bertahan hingga 13,4 Jam jika memiliki baterai berkapasitas 700 Ah.

\section{Kesimpulan}

Dalam penelitin "Rancang Bangun Pembangkit Listrik Portable Tenaga Surya dan Angin dengan Sistem Hybrid untuk Tempat Pengungsian Bencana Alam", di dapatkan kesimpulan sebagai berikut : 
1 Pada pengukuran solar cell didapatkan hasil semakin besar intensitas cahaya matahari maka didapatkan semakin besar arus dan tegangannya, untuk perolehan data pada pengukuran solar cell didapatkan tegangan tertinggi $20 \mathrm{~V}$ dan arus 1,16A pada cuaca cerah.

2 Pada pengukuran wind turbine didapatkan hasil semakin besar kecepatan angin maka didapatkan semakin besar tegangan yang dihasilkan. Untuk perolehan data pada pengukuran wind turbine didapatkan tegangan tertinggi yaitu $24 \mathrm{~V}$ dengan kecepatan angin 360Rpm.

3. Dengan sistem hybrid memiliki kelebihan pendapatan sumber tegangan dari 2 sumber berbeda, dimana pada alat ini sumber pertama dihasilkan oleh solar cell dan sumber kedua dihasilkan oleh wind turbine. Sehingga jika salah satu sumber pembangkit listrik tidak bekerja maka akan dibantu oleh pembangkit listrik kedua atau digunakan secara bergantian sesuai dengan kondisi alam di lapangan.

4. Dengan digunakannya model portable pada alat ini maka akan mempermudah proses transportasi serta perpindahan alat yang akan digunakan di tempat pengungsian bencana alam.

\section{Daftar Pustaka}

Y. I. Nakhoda and C. Saleh, "the Effect of Air Gap Distance Variation Between Stator and Rotor in Permanent Magnet Generator With Low Rotation Multi-Disc Axial Flux," JEEMECS (Journal Electr. Eng. Mechatron. Comput. Sci., vol. 3, no. 1, pp. 55-64, 2020, doi: 10.26905/jeemecs.v3i1.3999.

"Situs Kementrian Energi dan Sumber Daya Mineral, Energi Surya dan Pengembangan di Indonesia, 24 September 2009." http://majalahenergi.com.

S. Honsberg, Christiana \& Bowden, "Photovoltaic: Device, Systems, and Application PVCDROM 1.0.”.2009.

S. Pewarna, T. Sspt, T. Efisiensi, and J. Kimia, "Pengaruh Hubungan Seri-Paralel Pada Rangkaian Sel," 2009.

Ruskardi, "Kajian Teknis dan Analisis Ekonomis PLTS Off-Grid Solar System Sebagai Sumber Energi Alternatif," J. Tek. Elektro, vol. 7, no. 1, pp. 1-6, 2015, [Online]. Available: http://jurnal.untan.ac.id/index.php/Elkha/article/download/9409/9298.

P. Togan, "Perencanaan Sistem Penyimpanan Energi dengan Menggunakan Battery pada Pembangkit Listrik Tenaga Arus Laut ( PLTAL ) di Desa Ketapang, Kabupaten Lombok Timur , NTB .," pp. 1-6, 2009.

D. Perlanda, S. Alam, and S. Purwiyanti, "Alat Pengumpul Kopi Model Terhampar Secara Otomatis Berbasis Arduino Uno," Electrician, vol. 12, no. 1, p. 1, 2018, doi: 10.23960/elc.v12n1.2067.

Mario Roal, "Peningkatan Efisiensi Energi Menggunakan Baterai Dengan Kendali Otomatis 
Penerangan Ruang Kelas Berbasis PLTS," J. Elkha, vol. 7, no. Jurnal ELKHA Vol.7, No 2, Oktober 2015, pp. 12-19, 2015. 